
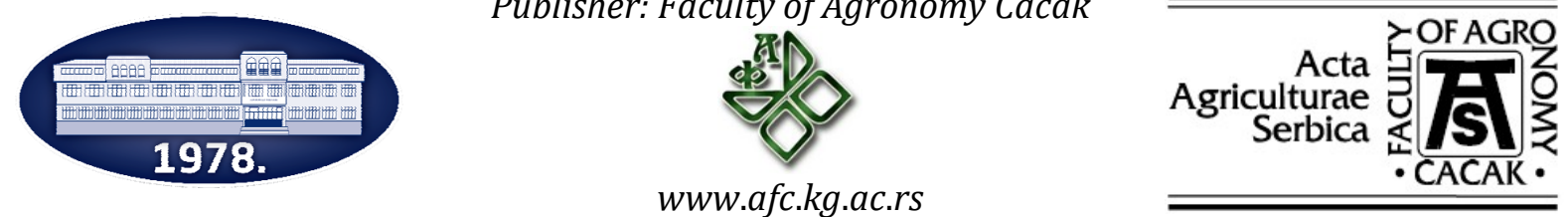

\title{
The impact of climate change on the corn yield in Serbia
}

\author{
Gordana Petrović, Darjan Karabašević, Svetlana Vukotić, Vuk Mirčetić, \\ Adriana Radosavac*
}

Faculty of Applied Management, Economics and Finance, University Business Academy in Novi Sad, Jevrejska 24, Belgrade, Serbia

*Corresponding author: adriana.radosavac@mef.edu.rs

Received 12 June 2020; Accepted 19 October 2020

\begin{abstract}
A B S T R A C T
The aim of the paper is to show the impact of climate factors on the corn yield in Serbia. Contemporary climate reports show that climate is changing, and the emission of greenhouse gases is one of the main causes of climate change. In three different locations (West Bačka District, Šumadija District and Nišava District) different climatic conditions and corn yield were analyzed for the period from 1991 to 2011. In the research process, the model of multiple linear regression and Pearson coefficient of correlation was applied. Obtained results has shown that there is a high correlation between parameters of climate conditions and variance of corn yield. A small amount of precipitation quantity and high maximum values of temperatures in the vegetation period influenced the decrease in yield, which was particularly noticed during the period from 2000 to 2007. A lower yield of corn was established compared to the average yield in all three observed districts, in the Šumadija district, the yield was lower $48 \%$ in 2000 and 52\% in 2007, in the West Bačka District, a yield was lower $40 \%$ in 2000 and $20 \%$ in 2007, and in the Nišava District, the yield was lower $65 \%$ in 2000 and $49 \%$ in 2007 . There are perennial variations of climatic factors, especially temperature and precipitation quantity, which affect the realization of the economic profitability of growing agricultural plant species. Losses in agriculture can be higher in conditions of an unstable climate. It is necessary to more precisely predict climate change and create new hybrids and varieties for cultivation that will be adaptable to changed climate conditions. Adaptations of plants to climatic conditions changes will contribute to greater economy of agricultural production, and the provision of food for the world's population.
\end{abstract}

Keywords: climate change, Serbia, climate conditions, corn, correlation, adaptation.

\section{И 3 В $О$ Д}

Циљ рада је да се прикаже утицај климатских фактора на принос кукуруза у Републици Србији. Бројни савремени извештаји показују да се клима мења, и да је емисија гасова који изазивају ефекат стаклене баште један од главних узрока промене климе. У три различите локације (Западнобачки округ, Шумадијски округ и Нишавски округ) су анализирани одређени климатски услови и принос кукуруза у временском периоду 1991-2011. година. За анализе је коришћен модел вишеструке линеарне регресије и Пирсонов коефицијент корелације. Добијени резултати су показали да постоји висок степен корелације између параметара климатских услова и варирања приноса кукуруза. Мала количина падавина и високе максималне вредности температура у вегетационом периоду утицале су на смањење приноса, које је нарочито било изражено током 2000. и 2007. године. У односу на просечни принос у сва три истраживана округа, установљен је нижи принос кукуруза и то: у шумадијском округу 48\%, у 2000. години а 52 \% у 2007. години. У западнобачком округу, такође је забележен нижи 40\%, у 2000. години и 20\% у 2007. години, а у нишавском округу принос је био нижи 65\% у 2000. години и 49 \% у 2007. години. Постоје вишегодишње варијације, климатских фактора, посебно температуре и падавина, које утичу на остваривање економске исплативости гајења пољопривредних биљних врста. Губици у пољопривреди могу бити и већи у условима нестабилне климе. Потребно је прецизније предвиђање климатских промена и стварање нових хибрида и сорти за гајење које ће бити адаптивне на промењене услове климе. Адаптације биљака на промене климатских услова допринеће већој економичности пољопривредне производње, и обезбеђењу хране за популацију људи.

Кључне речи: klimatske promene, Republika Srbija, klimatski uslovi, kukuruz, korelacija, adaptacija.

\section{Introduction}

One of the central issues facing the world is the risk of significant climate change, which poses a global environmental threat to all branches of the economy (Hong et al., 2019; Petrović et al., 2018a). Climate changes that directly affect agricultural production are the rapid increase of medium temperatures, and the frequent occurrence of extreme weather conditions will present significant difficulties in cultivating the land and providing food for the population (Taranto et al., 2018).

The global average temperature is increased by $0.85^{\circ} \mathrm{C}$ in a period from 1880 to 2012 , and scientifically the increase in temperature is explained by the increased concentration of greenhouse gases (carbon dioxide, methane, nitrogen dioxide) (IPCC, 2015; Henderson et al., 2015; Petrović et al., 2018b). There is an expectation that the temperature will continue to rise, and in a period from 2019 to 2035 will be 
increased by $0.3^{\circ} \mathrm{C}$ to $0.7^{\circ} \mathrm{C}$ compared to the period 1986-2005 (Falloon et al., 2015). There is a tendency to stop global warming at $1.5^{\circ} \mathrm{C}$ instead of $2^{\circ} \mathrm{C}$. In the study (Zampieri et al., 2019) found that changes of climatic factors in recent 10 years had detrimental affect to maize production and that the global warming will substantially increase the risk of maize production losses in most world regions. The objective is to strengthen the global response to climate change threats (IPCC, 2018), and the objective can be reached only by the implementation of effective leadership. Human activities that directly or indirectly affect the climate are referred to as anthropogenic factors (http://www.sepa.gov.rs/download/1_web.pdf).

Many climate change reports indicate that it will negatively affect agricultural production and on reducing the yield of varieties and hybrids (Luhunga, 2017) as well as the provision of food for the population. .One of the primary challenges of the 21st century is reducing food security risks from climate change consequences, as well as urgent adaptation actions to reduce risk. Increasing food production by $60 \%$ by 2050 to meet future consumption trends will also increase greenhouse gas emissions from the agricultural sector. Scenarios of limited global warming by $2^{\circ} \mathrm{C}$ related to the preindustrial level to the year 2100 indicate that agricultural production must be reduced. In this regard, society faces the challenges of adaptation and mitigation to provide food (Campbell et al., 2016). At $2{ }^{\circ} \mathrm{C}$ warming maize areas will be affected by heat stress and drought never experienced before, affecting many major and minor production regions. Sustainability of agricultural production is based on the cultivation of better-adapted varieties and hybrids and the application of appropriate cultivation technology (Knežević et al., 2015), which would reduce their sensitivity to changes in ecological conditions and generally to climate change (Ummenhofer et al., 2015). The application of this concept would significantly contribute to successful agricultural production to millions of producers in rural areas (Ceccarelli et al., 2010). Changes most often have adverse outcomes, and many agricultural systems become less productive, with economic and social consequences that affect the security of food supplying of the population (FAO, 2016).

In Serbia, the energy sector provides the highest percentage of greenhouse gas emissions, around 78\%, followed by the agricultural sector with $14.6 \%$ (Ministry of Agriculture and Environmental Protection, 2014). In order to avoid the dangers of climate change in the future, many countries and regions have set targets for reducing greenhouse gas emissions (ElRamady et al., 2012). Serbia was among the first countries in the Western Balkans region to adopt the NDC (Nationally Determined Contribution), with a defined target of $9.8 \%$ for the emission of harmful gases reduction by 2030 compared to emission in 1990 (Jovović and Jovičić, 2017).

Agriculture is traditionally one of the essential branches of the economy in Serbia. It employs a large number of people $(10 \%)$, either directly or indirectly, contributing significantly to the country's income, as it is one of the key components of economic development. It accounts for $9.5 \%$ of national GDP (2013) (Ministry of Environmental Protection, 2017). If the food industry is included in the agriculture share of GDP, its contribution is about $40 \%$. Agriculture estimates for $26 \%$ of exports and consequently significantly contributes to our country's income growth (Ministry of Environmental Protection, 2010).

As agriculture is vital for our country's economy and the people in rural areas, an approach to climate change adaptation is fundamental. Both rural and urban populations are highly dependent on this branch of the economy. Adapting to the negative impacts of climate change is essential to food security fostering.

The study aims to examine the existence of a correlation between selected climatic factors, which represent predictor variables and corn yield, which is selected as criterion variables. The core goal of the research is to analyze the impact of climatic factors through selected parameters (maximum temperature, minimum temperature, precipitation quantity, relative humidity and sunshine) on a particular agricultural crop (corn).

\section{Data and methodology}

Areas of Serbia were included in the research, which analyzes three regions: West Bačka District (Sombor, Kula, Apatin, Odžaci), Šumadija District (Kragujevac, Aranđelovac, Topola, Batočina, Lapovo, Knić, and Rača) and Nišava District (Niš, Aleksinac, Doljevac, Merošina, Ražanj, Gadžin Han and Svrljig).

Data on Climate conditions values for the research period from 1991 to 2011 are obtained using data from the Republic Hydrometeorological Institute of Serbia. Observed annual values of the state of the conditions of climate (maximum and minimum air temperature, precipitation quantity, humidity, and sunshine) processed on an annual basis in the main meteorological stations that exist at selected locations.

The research studied corn, as the most common field plant in Serbia. Data on the annual yield of selected agricultural crops, expressed in tons $(\mathrm{t})$ and $\mathrm{kg}$ $\mathrm{ha}^{-1}$, as well as on sown areas (ha) were obtained using data from the Statistical Office of the Republic of Serbia. All data were processed using the SPSS Statistics 25 software package.

This article has two starting hypotheses: null hypothesis $\mathrm{HO}$ and alternative hypothesis $\mathrm{H}_{1}$. The null hypothesis $\mathrm{H}_{\mathrm{o}}$ has been formulated negatively, arguing the opposite of the alternative hypothesis, and it states: There is no correlation between the dependent variable (crop yield) and the independent variable (conditions of climate).

Alternative Hypothesis $\mathrm{H}_{1}$ states: There is a correlation between the dependent variable (crop yield) and the independent variable (conditions of climate).

Hypothesis testing is based on one sample that is a dependent variable, and that is the annual corn yield in the Šumadija district $\left(\mathrm{kg} \mathrm{ha}^{-1}\right)$, while the independent variable is represented by climatic factors (maximum and minimum temperature, precipitation quantity, humidity, sunshine).

For correlation analysis of crop yield and conditions of climate Pearson's correlation coefficient was applied.

\section{Results and discussion}

Using the linear regression model, the null hypothesis No was tested. The obtained results show that the coefficient $(\mathrm{R})$ of multiple regressions is 0.773 and represents a credible prediction interval. The 
coefficient of determination (R Square) is 0.598 or $59.8 \%$ of the variability of the dependent variable, which can be explained by the independent variable. The adjusted value of the coefficient of determination
(Adjusted $\mathrm{R}$ Square) represents a less biased assessment of the coefficient of determination (Table 1).

Table 1.

Indicators of regression analysis for correlation of conditions of climate and crop yields

\begin{tabular}{|l|l|l|l|}
\hline Model Summary & R & R Square & Adjusted R Square \\
\hline Model & $0.773^{a}$ & 0.598 & 0.465 \\
\hline 1 & \multicolumn{3}{|l|}{ Pum, Humidity, Precipitation quantity. } \\
\hline a. Predictors: (Constant): Sunshine, T minimum, T maximum \\
\hline
\end{tabular}

Author's own calculations

The values presented in Table 2 indicate that if the probability is less than $0.05(0.011<0.05)$, the null hypothesis $\mathrm{HO}$ is rejected, which means that it makes sense to use the selected model to explain the correlation between crop yields and conditions of climate. In the following research, the degree of correlation and their statistical significance in the three selected locations will be determined using Pearson's correlation coefficient.

Table 2.

Indicators of regression analysis for correlation of conditions of climate and crop yields

\begin{tabular}{|c|c|c|c|c|c|}
\hline \multicolumn{7}{|c|}{ ANOVA $^{\text {a }}$} \\
\hline Model & Sum of Squares & $\mathrm{df}$ & Mean Square & F & Sig. \\
\hline Regression & 16980318.40 & 5 & 3396063.680 & 4.467 & $0.011^{\text {b }}$ \\
\hline Residual & 11402896.55 & 15 & 760193.103 & & \\
\hline Total & 28383214.95 & 20 & & & \\
\hline $\begin{array}{l}\text { a. Dependent Variable: Corn yield (kg ha-1) } \\
\text { b. Predictors: (Constant): Sunshine, T minimum, T maximum, Humidity, Precipitation quantity. } \\
\text { Author's own calculations }\end{array}$
\end{tabular}

Descriptive statistics are used in the initial phase of the research. This type of analysis was performed for temperature, precipitation, humidity, and insolation for the meteorological stations Sombor, Kragujevac, and Niš. The paper examines corn yield $\left(\mathrm{kg} \mathrm{ha}^{-1}\right)$, cultivated area (ha), and production $(\mathrm{t})$ in the selected locations.

Climate change has a substantial impact on agricultural production and the cultivation of all major crops. Variables that directly affect agricultural production are the rapid rise in mean temperatures and the increasing frequency and intensity of extreme weather events (Taranto et al., 2018). The methodology of descriptive statistics (Table 3) shows the state of selected conditions of climate on an annual basis for the meteorological stations Sombor, Kragujevac, and Niš for the period from 1991 to 2011. In the observed period, the highest value of the maximum temperature was $20.0{ }^{\circ} \mathrm{C}$ (Niš), $19.8{ }^{\circ} \mathrm{C}$ (Kragujevac) and $19.4{ }^{\circ} \mathrm{C}$ (Sombor). The minimum values of maximum temperature were $15.5^{\circ} \mathrm{C}$ (Sombor), $15.9{ }^{\circ} \mathrm{C}$ (Kragujevac) and $16.4{ }^{\circ} \mathrm{C}$ (Niš). Minimum values of minimum annual temperatures ranged from $5.3{ }^{\circ} \mathrm{C}$ to $5.8^{\circ} \mathrm{C}$ (Sombor $5.3^{\circ} \mathrm{C}$, Kragujevac $5.5^{\circ} \mathrm{C}$ and Niš $5.8^{\circ} \mathrm{C}$ ), while the highest values of minimum annual temperatures were between $7.2^{\circ} \mathrm{C}-8.0^{\circ} \mathrm{C}$ (Sombor 7.2 ${ }^{\circ} \mathrm{C}$, Kragujevac $7.6{ }^{\circ} \mathrm{C}$ and Niš $8.0{ }^{\circ} \mathrm{C}$ ). The data shows higher deviations at maximum temperatures (between its minimum and maximum values), and they are in a range from $3.6^{\circ} \mathrm{C}$ to $3.9^{\circ} \mathrm{C}$ compared to deviations at minimum temperatures (between its minimum and maximum values), where deviations are from $1.9^{\circ} \mathrm{C}$ to $2.2^{\circ} \mathrm{C}$. The average maximum temperature ranges from $17.1{ }^{\circ} \mathrm{C}$ (Sombor) to $18.4{ }^{\circ} \mathrm{C}$ (Niš). At minimum annual temperatures, mean values range from $6.3^{\circ} \mathrm{C}$ (Sombor) to $6.9^{\circ} \mathrm{C}$ (Niš). Standard deviation values confirm more significant deviations at maximum temperatures $(0.90$ 0.99 ) than at minimum temperatures (0.57-0.64). Estimating annual precipitation quantity in the selected period (1991-2011), notable deviations were observed in the minimum $(277.5 \mathrm{~mm}$ ) and maximum (1035.6 $\mathrm{mm}$ ) annual precipitation values recorded at the Sombor meteorological station. Due to the more significant difference in precipitation quantity in the aforementioned meteorological station compared to the other two meteorological stations (Niš and Kragujevac), the highest deviation from the mean value of $163.4 \mathrm{~mm}$ and the highest average annual precipitation quantity of $633.3 \mathrm{~mm}$ are also observed.

The lowest humidity values were recorded at the southernmost meteorological station (Niš), compared to the previous two meteorological stations (Kragujevac, Sombor). For a selected period of observation (1991-2011), the most hours of sunshine was registered at the Sombor meteorological station $(2127.6 \mathrm{~h})$. The highest deviation between the minimum annual (1745.9 h) and maximum annual $(2399.6 \mathrm{~h})$ hours of sunshine was recorded in the meteorological station Niš, and therefore, the standard deviation value (156.2) is also the largest. Approximately similar values of minimum and maximum annual values of sunshine were recorded at meteorological stations in Sombor and Kragujevac. The total increase of average annual temperature for Serbia due to climate change in the last century was $0.6^{\circ} \mathrm{C}$, which does not seem like a significant change.

The effects of climatic conditions on agriculture exist, which are registered in the comparison of yields during 
Table 3.

Conditions of climate in meteorological stations Sombor, Kragujevac and Niš in the period from 1991 to 2011

\begin{tabular}{|c|c|c|c|c|c|c|c|}
\hline \multicolumn{8}{|c|}{ Descriptive statistics - Conditions of climate } \\
\hline Variable & $\begin{array}{l}\text { Meteorological } \\
\text { station }\end{array}$ & Mean & $\begin{array}{c}\text { Std. } \\
\text { Deviation }\end{array}$ & Minimum & Maximum & Range & Variance \\
\hline \multirow{3}{*}{$\begin{array}{c}\text { Maximum } \\
\text { temperature } \\
\left({ }^{\circ} \mathrm{C}\right)\end{array}$} & Kragujevac & 17.8 & 0.9088 & 15.9 & 19.8 & 3.9 & 0.826 \\
\hline & Sombor & 17.1 & 0.9911 & 15.5 & 19.4 & 3.9 & 0.982 \\
\hline & Niš & 18.4 & 0.9788 & 16.4 & 20.0 & 3.6 & 0.958 \\
\hline \multirow{3}{*}{$\begin{array}{c}\text { Minimal } \\
\text { Temperature } \\
\left({ }^{\circ} \mathrm{C}\right)\end{array}$} & Kragujevac & 6.7 & 0.5750 & 5.5 & 7.6 & 2.1 & 0.331 \\
\hline & Sombor & 6.3 & 0.6361 & 5.3 & 7.2 & 1.9 & 0.405 \\
\hline & Niš & 6.9 & 0.6407 & 5.8 & 8.0 & 2.2 & 0.410 \\
\hline \multirow{3}{*}{$\begin{array}{l}\text { Precipitation } \\
\text { quantity }(\mathrm{mm})\end{array}$} & Kragujevac & 626.6 & 135.8805 & 378.8 & 839.5 & 460.7 & $18,463.498$ \\
\hline & Sombor & 633.3 & 163.4191 & 277.5 & $1,035.6$ & 758.1 & $26,705.811$ \\
\hline & Niš & 590.1 & 104.5827 & 385.6 & 756.3 & 370.7 & $10,937.532$ \\
\hline \multirow{3}{*}{$\begin{array}{l}\text { Humidity } \\
(\%)\end{array}$} & Kragujevac & 72.3 & 3.903 & 66 & 86 & 20 & 15.233 \\
\hline & Sombor & 71.5 & 3.737 & 63 & 79 & 16 & 13.962 \\
\hline & Niš & 69.3 & 2.617 & 64 & 73 & 9 & 6.848 \\
\hline \multirow{3}{*}{$\begin{array}{l}\text { Sunshine } \\
\text { (h) }\end{array}$} & Kragujevac & 2065.1 & 174.8304 & $1,803.5$ & 2449.6 & 646.1 & $30,565.666$ \\
\hline & Sombor & 2127.6 & 147.0386 & $1,871.8$ & 2449.3 & 577.5 & $21,620.355$ \\
\hline & Niš & 2002.9 & 156.2033 & $1,745.9$ & 2399.6 & 653.7 & $24,399.456$ \\
\hline
\end{tabular}

Author's own calculations

Multiple climatic variables, such as temperature, precipitation quantity, sunshine, and relative humidity, can affect crop yields, so the assumption is that there is a correlation between selected conditions of climate and selected agricultural crop (corn) for the analysis in the period from 1991 to 2011 . The correlation between annual values of the conditions of climate and corn yield ( $\left.\mathrm{kg} \mathrm{ha}^{-1}\right)$ is different in locations selected for the research process (Table 4).

\section{Table 4.}

Correlation between annual values of conditions of climate and agricultural crops Serbia at three different locations from 1991 to 2011

\begin{tabular}{|c|c|c|c|c|c|c|}
\hline \multirow{2}{*}{\multicolumn{2}{|c|}{$\begin{array}{c}\text { Agricultural crop } \\
\text { Conditions of climate }\end{array}$}} & \multicolumn{5}{|c|}{ Corn $\left(\mathrm{kg} \mathrm{ha}^{-1}\right)$} \\
\hline & & \multirow{2}{*}{$\begin{array}{c}\text { Maximum } \\
\text { Temp. }\left({ }^{\circ} \mathrm{C}\right) \\
-0.550^{* *}\end{array}$} & \multirow{2}{*}{$\begin{array}{c}\text { Minimum } \\
\text { Temp. }\left({ }^{\circ} \mathrm{C}\right) \\
0.059\end{array}$} & \multirow{2}{*}{$\begin{array}{c}\text { Precipitation } \\
\text { quantity (mm) } \\
0.400\end{array}$} & \multirow{2}{*}{$\begin{array}{c}\text { Humidity } \\
(\%)\end{array}$} & \multirow{2}{*}{$\begin{array}{c}\begin{array}{c}\text { Sunshine } \\
\text { (h) }\end{array} \\
-0.444^{*}\end{array}$} \\
\hline $\begin{array}{l}\text { West } \\
\text { Bačka }\end{array}$ & $\begin{array}{c}\text { Correlation } \\
\text { Coefficient }\end{array}$ & & & & & \\
\hline District & Sig. (2-tailed) & 0.010 & 0.799 & 0.073 & 0.143 & 0.044 \\
\hline & $\mathrm{N}$ & 21 & 21 & 21 & 21 & 21 \\
\hline \multirow{3}{*}{$\begin{array}{l}\text { Šumadija } \\
\text { District }\end{array}$} & $\begin{array}{c}\text { Correlation } \\
\text { Coefficient }\end{array}$ & -0.427 & -0.216 & 0.001 & 0.201 & $-0.592^{* *}$ \\
\hline & Sig. (2-tailed) & 0.053 & 0.347 & 0.996 & 0.382 & 0.005 \\
\hline & $\mathrm{N}$ & 21 & 21 & 21 & 21 & 21 \\
\hline \multirow{4}{*}{$\begin{array}{l}\text { Nišava } \\
\text { District }\end{array}$} & $\begin{array}{c}\text { Correlation } \\
\text { Coefficient }\end{array}$ & -0.235 & 0.126 & $0.624^{* *}$ & $0.808^{* *}$ & $-0.564^{* *}$ \\
\hline & Sig. (2-tailed) & 0.305 & 0.585 & 0.003 & 0.000 & 0.010 \\
\hline & $\mathrm{N}$ & 21 & 21 & 21 & 21 & 20 \\
\hline & \multicolumn{6}{|c|}{$\begin{array}{l}\text { **. Correlation is significant at the } 0.01 \text { level }(2 \text {-tailed) } \\
\text { *. Correlation is significant at the } 0.05 \text { level }(2 \text {-tailed) } \\
\text { Author's own calculations }\end{array}$} \\
\hline
\end{tabular}

Corn growing is practically impossible in areas where the mean summer temperature is below $19^{\circ} \mathrm{C}$, or where the average nighttime temperature drops below $13{ }^{\circ} \mathrm{C}$ during the summer months. The average annual precipitation quantity should not be less than $250 \mathrm{~mm}$ (Bekavac, 2012). Corn is sown throughout Serbia. About $70 \%$ of the area is located in the lowlands up to $300 \mathrm{~m}$ above sea level, and the rest, about $30 \%$, is located on mountainous terrain up to $700 \mathrm{~m}$ (Stojaković et al., 2010).

In the West Bačka District, corn is grown at 77,017 ha and yields 453,662 tons, or $5,909 \mathrm{~kg} \mathrm{ha}^{-1}$. There is a moderate negative correlation between corn and conditions of climate, moderate negative correlation between maximum temperature $(\mathrm{r}=-0.550)$ and sunshine $(\mathrm{r}=-\mathrm{0.444})$. The correlation for maximum 
temperature has no statistical significance $(0.010$ $=0.01$ ), while the correlation for sunshine has statistical significance $(0.044<0.05)$. In the Šumadija District, corn is planted in an average area size of 40,252 ha, and yields of 152,278 tons or $3,919 \mathrm{~kg} \mathrm{ha}^{-1}$. A moderate negative correlation is expressed for sunshine $(\mathrm{r}=-$ $0.592)$ and is statistically significant $(0.005>0.01)$.

In the Nišava District, corn is sown in average size areas of 30,024 ha. Yields are 100,438 tons or $3,470 \mathrm{~kg}$ ha $^{-1}$. There is a positive correlation with precipitation quantity ( $\mathrm{r}=0.624)$ and a very high positive correlation with humidity ( $\mathrm{r}=0.808)$. The correlation is statistically significant $(0.003<0.01$ and $0.000<0.01)$. When it comes to the correlation with the sunshine, it has a moderate negative value but has no statistical significance $(0.010=0.01)$.

Weather characteristics, especially precipitation and temperature regimes, play an essential role in the establishment of corn yield. Drought in combination with high air temperatures is considered to be a vital factor limiting corn yields (Markulj, 2010; Paunović et al., 2011). Therefore, the state must engage more in addressing drought problems. In this regard, national drought control committees have been established in many surrounding countries. One gets the impression that in Serbia, the problem of drought is too easily forgotten, after one or two rainy seasons (Dodig, 2006).

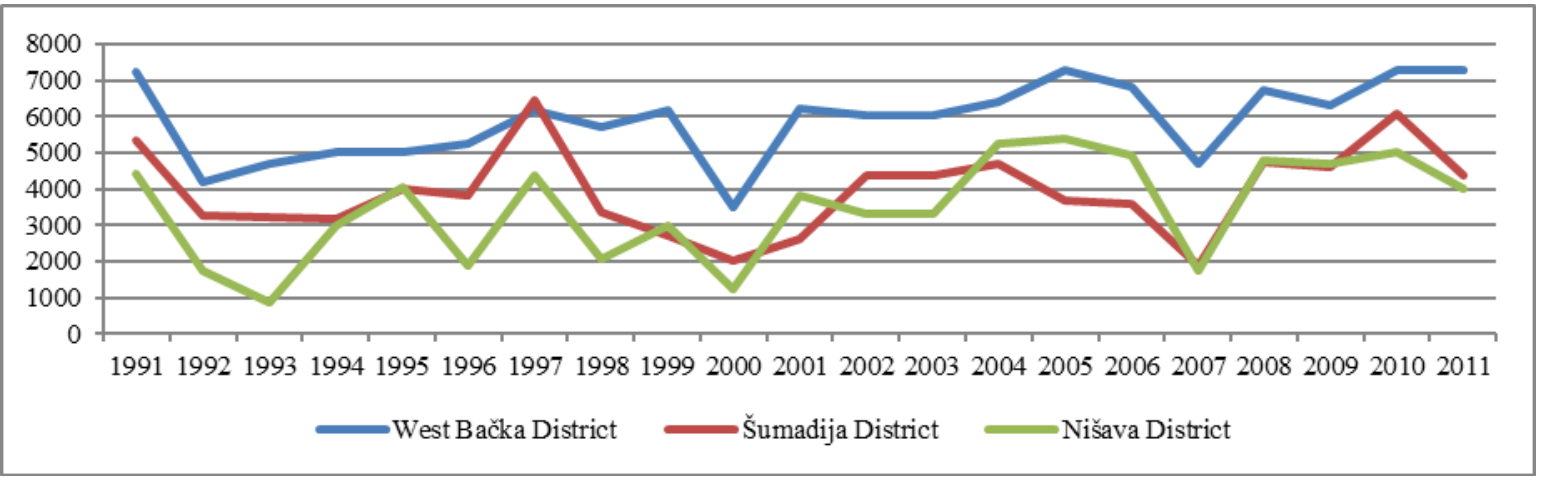

Figure 1. Realized corn yield kg ha-1) in West Bačka, Šumadija and Nišava District for the period 1991-2011

It is the most often considered that corn is drought-resistant and consume water economically. However, since it creates a huge vegetative mass, gives high yields, has an extended vegetation period, corn consumes large total amounts of water. In the absence of water, corn successfully overcomes drought, but gives lower yields, because plants consume more difficult accessible categories and forms of water from the soil (Pejić et al., 2009). Often the cause of reduced corn yield in our conditions is the lack of precipitation throughout the year, or the amount and distribution of precipitation during the vegetation period (Kovačević et al., 2010; Paunović et al., 2012). In the selected observation period, there was a sharp decline in yields in 2000 (West Bačka District 3,505 kg ha-1, Šumadija District 2,018 $\mathrm{kg} \mathrm{ha}^{-1}$ and Nišava district $1,234 \mathrm{~kg} \mathrm{ha}^{-1}$ ) and in 2007 (West Bačka District 4,699 kg ha-1, Šumadija District $1,868 \mathrm{~kg}^{-1} \mathrm{ha}^{-1}$ and Nišava District $1759 \mathrm{~kg} \mathrm{ha}^{-1}$ ).

Table 5.

Monthly precipitation amount (mm) during the vegetation period (April-September) from 1991 to 2011 in Šumadija, Nišava and West Baška districts

\begin{tabular}{|c|c|c|c|c|c|c|c|}
\hline & \multicolumn{6}{|c|}{ Observed period 1991-2011 } & \multirow[b]{2}{*}{ Total } \\
\hline & April & May & June & July & August & September & \\
\hline Optimal value & 50.0 & 75.0 & 90.0 & 100.0 & 95.0 & 80.0 & 490.0 \\
\hline Šumadija District & 55.2 & 55.4 & 70.0 & 64.3 & 61.4 & 59.2 & 365.5 \\
\hline Nišava District & 56.7 & 59.6 & 56.0 & 45.2 & 45.8 & 55.5 & 318.8 \\
\hline $\begin{array}{l}\text { West Bačka } \\
\text { District }\end{array}$ & 43.2 & 57.2 & 74.4 & 78.0 & 55.0 & 61.5 & 369.3 \\
\hline
\end{tabular}

Author's own calculations

Our agroecological conditional-optimal needs of corn for water, at average air temperatures, are as follows: April - $50 \mathrm{~mm}$, May - $75 \mathrm{~mm}$, June - $90 \mathrm{~mm}$, July - $100 \mathrm{~mm}$, August - $95 \mathrm{~mm}$ and September - 80 $\mathrm{mm}$, the total for the vegetation period $490 \mathrm{~mm}$ (Jaramaz, 2015). When analyzing the period 19912011 , it is noticed that the average precipitation quantity for April was above the optimal in the territory of Šumadija $(55.2 \mathrm{~mm})$ and Nišava district (56.7 mm), while in West Bačka district $(43.2 \mathrm{~mm})$ it was below the optimal value. During the following months (May-September), the average precipitation quantity values at the selected locations were below the optimal ones. The total amount of precipitation quantity during the vegetation period at the selected locations was also below the optimal value. During the vegetation period in the selected period (1991-2011), the lowest amount of precipitation quantity was at the location of the West Bačka district in 2000 (June - 9.8 $\mathrm{mm}$ and August - $5.5 \mathrm{~mm}$ ), 2003 (April - $7.8 \mathrm{~mm}$ ) and 
2007 (April - $0.5 \mathrm{~mm}$ ). In the Šumadija district in the vegetation period of corn, the lowest amount of precipitation quantity was in 2003 (August - $5.1 \mathrm{~mm}$ ) and 2007 (April - $3.6 \mathrm{~mm}$ ), while in the Nišava district it was recorded in 1996 (July - $5.5 \mathrm{~mm}$ ), 2000 (August $6.5 \mathrm{~mm}$ ), 2007 (July $-7.7 \mathrm{~mm}$ ) and 2011 (August - 4.1 $\mathrm{mm})$.

If each year is separately analysed during the vegetation period of corn, it is noticed that in the territory of Šumadija district the amount of precipitation quantity was above the optimal, in 1999 (603.4 mm), $2001(631.7 \mathrm{~mm})$ and 2005 (509.6 mm) years. In the Nišava district, it was only in 2001 (493.2 $\mathrm{mm})$, while in the West Bačka district it was in 2001 (535.6 $\mathrm{mm}$ ) and 2005 (590.4 $\mathrm{mm})$. The lowest amount of precipitation quantity during the vegetation period was recorded in the West Bačka district in 2000 (138.2 $\mathrm{mm}$ ) and 2003 (177.9 $\mathrm{mm}$ ).

It must be emphasized that corn yields also depend on the location where they are grown, but in this case, in addition to the previously mentioned fact, a significant role in reducing yields had a very small amount of precipitation quantity in certain months during the growing season.

Table 6.

Mean monthly temperatures $\left(\mathrm{C}^{\circ}\right)$ during the vegetation period (April-September) from 1991 to 2011 in Šumadija, Nišava and West Bačka district

\begin{tabular}{|c|c|c|c|c|c|c|c|}
\hline & \multicolumn{6}{|c|}{ Observed period 1991-2011 } & \multirow[b]{2}{*}{$\begin{array}{l}\text { Average for the } \\
\text { growing season }\end{array}$} \\
\hline & April & May & June & July & August & September & \\
\hline $\begin{array}{l}\text { Optimal value } \\
\text { according to } \\
\text { Stepanov }\end{array}$ & 15.0 & 18.0 & 20.0 & 23.0 & 23.0 & 18.0 & 20.0 \\
\hline $\begin{array}{c}\text { Šumadija } \\
\text { District }\end{array}$ & 11.7 & 16.7 & 20.4 & 22.3 & 22.0 & 16.8 & 18.3 \\
\hline Nišava District & 12.2 & 17.2 & 20.9 & 22.9 & 22.8 & 17.5 & 18.9 \\
\hline $\begin{array}{l}\text { West Bačka } \\
\text { District }\end{array}$ & 11.8 & 17.3 & 20.7 & 22.2 & 21.8 & 16.4 & 18.3 \\
\hline
\end{tabular}

Author's own calculations

The most significant production of corn takes place in areas where the isotherms of the warmest month range from $21^{\circ} \mathrm{C}$ to $27^{\circ} \mathrm{C}$, and the period without frost last 120-180 days. It is clear that the reaction of a plant depends on a combination of specific stress factors, the intensity of each stress and the stage of plant development (Bekavac, 2012; Rejeb et al., 2014). During the dry year of 2000, the maximum values of temperatures in selected locations were in August (West Bačka district $32.3^{\circ} \mathrm{C}$, Šumadija district $32.4^{\circ} \mathrm{C}$ and Nišava district $33.5{ }^{\circ} \mathrm{C}$ ), while in 2007 the maximum values of temperatures were in the vegetation period in July (West Bačka district $31.5^{\circ} \mathrm{C}$, Šumadija district $33.3^{\circ} \mathrm{C}$ and Nišava district $35.2^{\circ} \mathrm{C}$ ).

Studies by other authors have shown that there is a negative impact of both high temperature and drought on the growth, development and reproduction of cereals and that it affects agricultural crop productivity (Ihsan et al., 2016; Zandalinas et al., 2018).

The analysis of the mean air temperature (Table 6) for the observation period (1991-2011) shows that in April and May, the mean air temperatures at the selected locations were below the optimal value. During June, they are slightly above the optimal value, while during July and August, the values are around optimal value. In September, air temperatures are again below the optimal value.

During the multi-year period at selected locations, it is noticed that April was the warmest in 2000 with the highest values of $15.1{ }^{\circ} \mathrm{C}$ in Šumadija district, 15.0 ${ }^{\circ} \mathrm{C}$ in Nišava district and $14.5^{\circ} \mathrm{C}$ in West Bačka district. May was the warmest in 2003 (Šumadija district 19.9 ${ }^{\circ} \mathrm{C}$, Nišava district $20.2^{\circ} \mathrm{C}$, West Bačka district $20.5^{\circ} \mathrm{C}$ ), while June was the warmest in 2003 (Šumadija district $23.3^{\circ} \mathrm{C}$, Nišava district $23.5^{\circ} \mathrm{C}$, West Bačka district 24.6 ${ }^{\circ} \mathrm{C}$ ) and 2007 (Šumadija district $22.9^{\circ} \mathrm{C}$, Nišava district $23.6^{\circ} \mathrm{C}$, West Bačka district $22.3^{\circ} \mathrm{C}$ ). The highest values of mean July temperatures were in 1995. (Šumadija district $23.6{ }^{\circ} \mathrm{C}$, Nišava district $24.0{ }^{\circ} \mathrm{C}$, West Bačka district $23.9{ }^{\circ} \mathrm{C}$ ) and 2007 (Šumadija district $24.8^{\circ} \mathrm{C}$, Nišava district $26.2^{\circ} \mathrm{C}$, West Bačka district $23.6^{\circ} \mathrm{C}$ ). The highest average air temperatures during August were in 1992 (Šumadija district $24.7^{\circ} \mathrm{C}$, Nišava district 25.6 ${ }^{\circ} \mathrm{C}$, West Bačka district $24.8^{\circ} \mathrm{C}$ ), 2000 (Šumadija district $23.9^{\circ} \mathrm{C}$, Nišava district $24.6^{\circ} \mathrm{C}$, West Bačka district 23.9 ${ }^{\circ} \mathrm{C}$ ) and 2003 (Šumadija district $24.6{ }^{\circ} \mathrm{C}$, Nišava district $25.1{ }^{\circ} \mathrm{C}$, West Bačka district $24.5^{\circ} \mathrm{C}$ ). September was the warmest in 1992. (Šumadija district $20.7^{\circ} \mathrm{C}$, Nišava district $21.7^{\circ} \mathrm{C}$, West Bačka district $21.7^{\circ} \mathrm{C}$ ) and 2011 (Šumadija district $20.2^{\circ} \mathrm{C}$, Nišava district $21.6^{\circ} \mathrm{C}$, West Bačka district $21.6^{\circ} \mathrm{C}$ ).

Researches show that climate change will affect corn yield, in conditions without irrigation, where the yield can be reduced by $58 \%$ for the period until 2030 , or up to $73 \%$ for the period until 2050 . In the case of irrigation, a smaller decrease in yield could be expected, up to $15 \%$ for the period until 2030 , or up to $25 \%$ for the period until 2050 . According to estimates, changes in corn yields by 2100 , without irrigation, range from $-52 \%$ to $-22 \%$, ranging from northern and western to eastern and southern parts of Serbia (Ministry of Agriculture and Environmental Protection, 2015).

Climate change izražene through temperature increase can have positive and negative effects on crop yield, it has been found that an increase in temperature will have a negative effect on cereals (Adams et al., 1998; Mićanović et al., 2017). The global climate change scenario shows that in 2100 , corn yields will be lower from $20 \%$ to $45 \%$ and wheat yields from $5 \%$ to $50 \%$ (FAO, 2016). Corn yields are quite sensitive to the effects of climate change associated with high daily temperatures that accelerate the phenological phase 
transitions of corn, decreasing yields (Tebaldi and Lobell, 2018).

Estimates of annual damage to agriculture due to temperature increases or extended periods of drought will be more costly than damages in other activities. One possible solution to counteract the effects of climate change is to look for agricultural crops and varieties that are adapted to highly variable, extreme climates (Kovačević et al., 2011; Korres et al., 2016; Luhunga, 2017).

\section{Conclusion}

In Serbia, in the period from 1960 to 2012, the temperature increased by an average of $0.3^{\circ} \mathrm{C}$ per decade, the variation of which, especially in the period of vegetative development of corn, has an impact on yield, economy of agricultural production and food supply for the population.

Agriculture production suffers from the negative impact of climate change, and at the same time, it is a source of emissions of gases that contribute to the emergence of climate change.

Extreme weather events, especially droughts, more dry days and days with extreme temperatures, play a crucial role in the effects of climate change on the yields of the most important agricultural crops.

At selected locations in Serbia, highly significant correlations were established between monthly temperatures, precipitation quantity, sunshine, humidity and corn yield, and they resulted in different yields.

During the vegetation period, corn needs precipitation, which showed a positive and very strong correlation. Increased duration of sunshine (positive correlation) affected the growth of maximum temperatures with extremely high values $\left(33-35^{\circ} \mathrm{C}\right)$, and this had a negative effect on the formation of corn yield during the growing season, which shows the correlation that had a negative trend.

In contrast to air temperature, the correlation between precipitation and corn yield had a very positive trend. Although corn is drought tolerant, during the vegetation period (April-September), it needs a vast amount of water to form a vegetative mass. The lowest precipitation quantity at the selected locations was most often in 2000, 2003 and 2007, and the West Bačka district (138.2 $\mathrm{mm}$ and $177.9 \mathrm{~mm}$ ) had a very small amount of precipitation compared to the other two locations.

Extremely high temperatures and low precipitation quantity had a negative effect on corn yield, especially during 2000 and 2007, whose values were the lowest in the selected observation period.

Rising temperatures, reduced availability of water for irrigation and floods will be the main limiting factors in maintaining and increasing crop productivity and represent predictions for future climate scenarios.

Within the global strategy, a strategy for adapting to climate change must be developed and implemented in Serbia as well, especially in the agricultural sector. It is necessary to create new varieties and hybrids adaptable to extreme climate conditions and to improve the technology of growing varieties and hybrids to mitigate the consequences of global warming (from drought, flood, frost). Also, it is necessary to limit the reduction of activities that contribute to the warming of the atmosphere and climatic factors changes.

The challenges ahead are sustainability and competitiveness in order to achieve targeted production and to meet growing food needs.

\section{References}

Adams, R. M., Hurd, B. H., Lenhart, S., Leary, N. (1998). Effects of global climate change on agriculture: an interpretative review. Climate research, 11(1), 19-30.

Bekavac, G. (2012). Vodič za organsku proizvodnju kukuruza (Manual for organic production of maize), GIZ- Nemačka organizacija za internacionalnu saradnju GmbH; Novi Sad: Institut za ratarstvo i povrtarstvo (Zemun: Dunav), https://www.nsseme.com/blog/wpcontent/uploads/2013/01/Vodic-za-organskuproizvodnju-kukuruza.pdf (accessed on 20.5.2020).

Campbell, B. M., Vermeulen, S. J., Aggarwal, P. K., CornerDolloff, C., Girvetz, E., Loboguerrero, A. M., RamirezVillegas, J., Rosenstock, T., Sebastian, L., Thornton, P.K., Wollenberg, E. (2016). Reducing risks to food security from climate change. Global Food Security, 11, 34-43.

Ceccarelli, S., Grando, S., Maatougui, M., Michael, M., Slash, M., Haghparast, R., Rahmanian , M., Taheri, A., Al-Yassin, A., Benbelkacem,A., Labdi, M., M Imoun, H., Nach it, M. (2010): Plant breeding and climate changes. The Journal of Agricultural Science, 148 (6), 627-637.

Dodig, D., Spasov, P., Miletić, R. (2006). The Occurrence of Drought and its Effects on Plant Production in Eastern Serbia. Acta Agriculturae Serbica, 11(21), 45-51.

El-Ramady, H.R., Belal, A-A., El-Marsafawy, S.M., Shehata, S.A., Yehia, S.Z.A., Belal, E-S.B. (2012). Contemporary Environmental Readings. Volume 1 Climate Change A Blessing or a Curse for Agriculture. LAP, Germany.

Falloon, P., Bebber, D., Bryant, J., Bushell, M., Challinor, A. J., Dessai, S., Gurr, S., Koehler, A. K. (2015). Using climate information to support crop breeding decisions and adaptation in agriculture. World Agriculture, 5(1), 25-43.

FAO (2016). The state of food and agriculture. Climate change, agriculture and food security.

Food and Agriculture Organization of the United Nations (2016). Climate change and food security: Risks and responses.

Henderson, R. M., Reinert, S. A., Dekhtyar, P., Migdal, A. (2015). Climate Change in 2018: Implications for Business risk. Harvard Business School.

Hong, H., Li, F.W., Xu, J. (2019). Climate risks and market efficiency. Journal of Econometrics, 208 (1): 265-281.

Ihsan, M.Z., El-Nakhlawy, F.S., Ismail, S.M., Fahad, S., Daur, I. (2016). Wheat phenological development and growth studies as affected by drought and late season high temperature stress under arid environment. Frontiers in Plant Science, 7, 795.

IPCC (2015). Climate Change 2014. The Intergovernmental panel on climate change. Geneva, Switzerland.

IPCC (2018). Special report Global Warming of $1.5{ }^{\circ} \mathrm{C}$. Chapters 1. Framing and Context.

Jaramaz, M. M. (2015). Uticaj gustine useva na prinos i kvalitet zrna kukuruza u uslovima navodnjavanja i prirodnog vodnog režima. Doktorska disertacija. Poljoprivredni fakultet Zemun.

Jovović, M. A., Jovičić, B. (2017). Strategija komunikacije za oblast klimatskih promena. OEBS, Beograd.

Knežević, D., Radosavac, A., Zelenika, M. (2015). Variability of grain weight per spike of wheat grown and diferent ecological conditions. Acta Agriculturae Serbica, 20(39), 85-95.

Korres, N. E., Norsworthy, J. K., Tehranchian, P., Gitsopoulos, T. K., Loka, D. A., Oosterhuis, D.M., Gealy, D.R., Moss, S.R., Burgos, N.R., Miller, M.R., Palhano, M. (2016). Cultivars to face climate change effects on crops and weeds: a review. Agronomy for Sustainable Development, 36: 12.

Kovačević, V., Paunović, A., Knežević, D., Biberdžić, M., Josipović, M. (2010). Uticaj vremenskih prilika na prinos kukuruza u periodu 2000-2007. godine. XV Savetovanje o 
biotehnologiji, Zbornik radova, Agronomski fakultet Čačak, 26-27 mart 2010., 15 (16): 13-20, Čačak, Srbija.

Kovačević, V., Šimić, D., Kadar, I., Knežević, D., Lončarić, Z. (2011). Genotype and liming effects on cadmium concentration in maize (Zea mays L.). Genetika, 43(3), 607-615.

Luhunga, P.M. (2017). Assessment of the Impacts of Climate Change on Maize Production in the Southern and Western Highlands Sub-agro Ecological Zones of Tanzania. Frontiers in Environmental Science, 5.

Markulj, A., Marijanović, Tkalec, M., Jozić, A., Kovačević, V. (2010). Effects of Precipitation and Temperature Regimes on Maize (Zea mays L.) Yields in Northwestern Croatia. Acta Agriculturae Serbica, 15(29), 39-45.

Mićanović, D., Knežević, D., Zečević, V. (2017). Effects of model in agriculture. Proceedings of the 4th International Science Conference Agriusiness MAK 2017, „European Road" IPARD 2015-2020, Kopaonik, January 2728th 2017, 60-69, Serbia.

Ministry of Agriculture and Environmental Protection (2014). Serbia and climate changes. Cekor, Belgrade.

Ministry of Agriculture and Environmental Protection (2015). The first biennial updated report of the Republic of Serbia according to the UN Framework Convention on Climate Change. Belgrade.

Ministry of Environmental Protection (2010). The first report of the Republic of Serbia under the United Nations Framework Convention on Climate Change. Belgrade.

Ministry of Environmental Protection (2017). The second report of the Republic of Serbia according to the United Nations Framework Convention on Climate Change. Belgrade.

Paunović, A., Đalović, I., Jocković, Đ., Kovačević, V., Jelić, M., Knežević, D. (2011). Analiza proizvodnje kukuruza na području Šumadije i zapadne Srbije u periodu 2003-2009. godine. XVI Savetovanje o biotehnologiji sa međunarodim učešćem, Zbornik radova, Agronomski fakultet Čačak, 45. mart 2011. godine, 16(18), 171-176.

Paunović, A., Kovačević, V., Knežević, D., Jelić, M., Madić, M., Rastija, M., Iljkić, D., Knežević, J. (2012). Maize yield variation in Northen Serbian and Eastern Croatian regions. 47th Croatian and 7th International Symposium on Agriculturae, Faculty of Agriculturae Zagreb, 13th17th February, Opatija, Croatia.

Pejić, B., Bošnjak, Đ., Mačkić, K., Stričević, R., Simić, D., Drvar, A. (2009). Osetljivost kukuruza (Zea mays L.) na deficit vode u zemljištu u određenim pod periodima vegetacije. Letopis naučnih radova, 33(1), 155-166.

Petrović, G., Karabašević, D., Maksimović, M. (2018a). Uticaj klimatskih promena na povećanje temperature vazduha. Bizinfo (Blace), 9(1), 59-72.

Petrović, G., Karabašević, D., Maksimović, M. (2018b). Uticaj energenata na emisiju ugljen-dioksida $\mathrm{i}$ klimatske promene. Bakar, 43(1), 17-30.

Rejeb, I.B., Pastor, V., Mauch-Mani, B. (2014). Plant responses to simultaneous biotic and abiotic stress: Molecular mechanisms. Plants, 3, 458-475.

Stojaković, M., Jocković, Đ., Ivanović, M., Bekavac, G., Nastasić, A., Purar, B., Stanisavljević D., Popov R., Čapelja V., Lajišić R., Dolapčev S., Stojaković Ž. (2009). Specifičnosti reakcije hibrida kukuruza u različitim agroekološkim uslovima. Zbornik radova Instituta za ratarstvo i povrtarstvo, 46(2): 335-344.

Taranto, F., Nicolia, A., Pavan, S., De Vita, P., D’Agostino, N. (2018). Biotechnological and Digital Revolution for Climate-Smart Plant Breeding. Agronomy, 8(12), 277.

Tebaldi, C., Lobell, D. (2018). Differences, or lack thereof, in wheat and maize yields under three low-warming scenarios open access differences, or lack thereof, in wheat and maize yields under three low-warming scenarios. Environmental Research Letters, 13(6), 065001.

Ummenhofer, C. C., Xu, H., Twine, T. E., Girvetz, E. H., McCarthy, H. R., Chhetri, N., Nicholas, K. A. (2015). How Climate Change Affects Extremes in Maize and Wheat Yield in Two Cropping Regions. Journal of Climate, 28(12), 46534687.

Zampieri, M., Ceglar, A., Dentener, F., Dosio, A., Naumann, G., van den Berg, M., Toreti, A. (2019). When will current climate extremes affecting maize production become the norm? Earth's Future, 7, 113-122.

Zandalinas, S.I., Mittler, R., Balfagón, D., Arbona, V., GómezCadenas, A. (2018): Plant adaptations to the combination of drought and high temperatures. Physiologia plantarum, 162(1),2-12. 